\title{
Psychiatric Disorder Criteria and their Application to Research in Different Racial Groups Nancy CP Low ${ }^{1}$ and John Hardy*2
}

\author{
Address: ${ }^{1}$ Section on Developmental Genetic Epidemiology, National Institute of Mental Health, 35 Convent Drive, MSC 3720, Bethesda, \\ Maryland 20892-3720, USA and 2Laboratory of Neurogenetics, NIA Intramural Research Program, Porter Neuroscience Building, NIH Main \\ Campus, Bethesda, Maryland 20892, USA \\ Email: Nancy CP Low - lown@mail.nih.gov; John Hardy* - hardyj@mail.nih.gov \\ * Corresponding author
}

Published: 10 January 2007

BMC Psychiatry 2007, 7:1 doi:10.1 186/147I-244X-7-1
Received: 01 September 2006

Accepted: 10 January 2007

This article is available from: http://www.biomedcentral.com/I47I-244X/7/I

(c) 2007 Low and Hardy; licensee BioMed Central Ltd.

This is an Open Access article distributed under the terms of the Creative Commons Attribution License (http://creativecommons.org/licenses/by/2.0), which permits unrestricted use, distribution, and reproduction in any medium, provided the original work is properly cited.

\begin{abstract}
Background: The advent of standardized classification and assessment of psychiatric disorders, and considerable joint efforts among many countries has led to the reporting of international rates of psychiatric disorders, and inevitably, their comparison between different racial groups.

Results: In neurologic diseases with defined genetic etiologies, the same genetic cause has different phenotypes in different racial groups.

Conclusion: We suggest that genetic differences between races mean that diagnostic criteria refined in one racial group, may not be directly and simply applicable to other racial groups and thus more effort needs to be expended on defining diseases in other groups. Cross-racial confounds (in addition to cultural confounds) make the interpretation of rates in different groups even more hazardous than seems to have been appreciated.
\end{abstract}

\section{Text}

The DSM [1] and ICD [2] psychiatric disorder criteria represent the extracted wisdom of predominantly Caucasian psychiatrists treating predominantly Caucasian patients. They have been useful clinically for the important pragmatic reasons that, within this group, they facilitate efficient communication between physicians about patients, reporting on morbidity and mortality statistics, attempts at common treatments, and billing of third party payers. However, they have little biological validity and there is no evidence that they reflect etiology. They have opened the door to many pharmacologic and behavioral intervention trials [3-6] and etiologic investigations that have, in general, been disappointing. However, these disordered symptom clusters (often comprised of variations in normal human feelings) reflect complexity that we have not been able to fully appreciate and this is in part due to our obscured vision of them through the lens of DSM/ICD classification.

Despite this derivation, cross-racial comparisons of disorder rates are a frequent topic of investigation and interpretation $[7,8]$. While most researchers would accept that it is challenging to compare diagnostic rates of psychiatric disorders across cultures [9] they have not considered the possibility that clinical manifestations of the same etiology may be different in people of different genetic backgrounds (that is, their race).

While clinical neurological diagnoses are essentially made by the same operational process of clinical consensus, these clinical diagnoses have traditionally been validated 
through neuropathological examination. In many cases, this biological validation can be made since the genetic etiologies of many neurological diseases are now known. In the limited number of times this biological validation has been compared retrospectively against the clinical (and pathologic) characterization of neurological disease, it has become clear that the clinical characterization holds up poorly in different racial groups. For example, the phenotypes of both Spinocerebellar Ataxia types 2 and 3 (SCA2 and SCA3) are different in Eastern Asians and SubSaharan-Africans respectively from their phenotypes in Caucasians [10-13]. Dentatorubral-Pallidoluysian Atrophy in the Japanese is different from Haw River syndrome in African-Americans despite being caused by the same polyglutamine expansion $[14,15]$. Presenilin mutations present with Alzheimer's disease with a predominantly early memory change in Caucasians, but seem to present with personality change in those of African descent [16]. These differences in clinical phenotypes are reminiscent of the differences seen in different strains of transgenic mice with the same transgene [17] and should not be surprising to geneticists $[18,19]$. The process of validation through biological examination is not possible in psychiatric diagnoses (though many attempts are underway in the search for "endophenotypes" or biomarkers); in fact, many psychiatric syndromes are mimicked by known medical disorders, such as, hyper/hypothyroidism, pancreatic cancer, hyperparathyroidism, lyme disease (mood changes, mania, depression); hypo/hyperglycemia, pheochromocytoma (panic), thiamine deficiency, normal pressure hydrocephalus (dementia, cognitive changes), lead poisoning (attention deficit hyperactivity disorder), etc., and a psychiatric diagnosis is only made following their exclusion, as the DSM-IV dictates.

Given this precedent, it seems ill advised to interpret any differences in disorder rates between different racial groups as being indicative of different rates of exposures to risk factors. This potential for confounding genetic variability is in addition to the more widely recognized, culturally derived issues inherent in the interpretation of most "risk factors" in psychiatric disorders, such as parenting styles, low socioeconomic status, temperament, or psychological "trauma." Since the diagnostic criteria have been imperfectly tuned to ensure, as far as possible, that everyone with mental illness in a Caucasian population receives a diagnosis (for billing, treatment, etiologic study and needs assessment surveys), it should not be surprising to find that the rates in non-Caucasians would be different. Therefore, even given identical exposures, one should expect lower rates of DSM/ICD categories in non-Caucasians since less people in those groups would fit comfortably a diagnostic category. The limited data available suggest this is generally the case [18]. This does not imply that the burden of mental distress is less in other races, but rather our instruments of assessment and diagnosis are less appropriately applied in such genetically different individuals.

\section{Abbreviations}

DSM - Diagnostic and Statistical Manual of Mental Disorders; ICD - International Classification of Diseases.

\section{Competing interests}

The author(s) declare that they have no competing interests.

\section{Authors' contributions}

$\mathrm{JH}$ and NL conceived of the manuscript. JH drafted the initial version and both participated in multiple revisions until the final version.

\section{References}

I. American Psychiatric Association: Diagnostic and Statistical Manual of Mental Disorders, Fourth Edition - Text Revision (DSM-IV-TR).

2. World Health Organization: International Statistical Classification of Diseases and Related Health Problems, I Oth Revision (ICD- I0).

3. Butler AC, Chapman JE, Forman EM, Beck AT: The empirical status of cognitive-behavioral therapy: a review of meta-analyses. Clin Psychol Rev 2006, 26(I):|7-3|.

4. Rush AJ, Trivedi MH, Wisniewski SR, Stewart JW, Nierenberg AA Thase ME, Ritz L, Biggs MM, Warden D, Luther JF, Shores-Wilson K, Niederehe G, Fava M: Bupropion-SR, sertraline, or venlafaxineXR after failure of SSRIs for depression. N Engl J Med 2006, 354(I 2): | $23|-| 242$.

5. Stroup TS, Alves WM, Hamer RM, Lieberman JA: Clinical trials for antipsychotic drugs: design conventions, dilemmas and innovations. Nat Rev Drug Discov 2006, 5(2): | 33-|46.

6. Vieta E, Pacchiarotti I, Scott J, Sanchez-Moreno J, Di Marzo S, Colom F: Evidence-based research on the efficacy of psychologic interventions in bipolar disorders: a critical review. Curr Psychiatry Rep 2005, 7(6):449-455.

7. Breslau J, Aguilar-Gaxiola S, Kendler KS, Su M, Williams D, Kessler $\mathrm{RC}$ : Specifying race-ethnic differences in risk for psychiatric disorder in a USA national sample. Psychol Med 2006, 36(I):57-68.

8. Demyttenaere K, Bruffaerts R, Posada-Villa J, Gasquet I, Kovess V Lepine JP, Angermeyer MC, Bernert S, de Girolamo G, Morosini P, Polidori G, Kikkawa T, Kawakami N, Ono Y, Takeshima T, Uda H, Karam EG, Fayyad JA, Karam AN, Mneimneh ZN, Medina-Mora ME, Borges G, Lara C, de Graaf R, Ormel J, Gureje O, Shen Y, Huang Y, Zhang M, Alonso J, Haro JM, Vilagut G, Bromet EJ, Gluzman S, Webb C, Kessler RC, Merikangas KR, Anthony JC, Von Korff MR, Wang PS, Brugha TS, Aguilar-Gaxiola S, Lee S, Heeringa S, Pennell BE, Zaslavsky $A M$, Ustun TB, Chatterji S: Prevalence, severity, and unmet need for treatment of mental disorders in the World Health Organization World Mental Health Surveys. Jama 2004, 29 I(2I):258I-2590.

9. Mezzich JE, Kirmayer LJ, Kleinman A, Fabrega H Jr., Parron DL, Good B], Lin KM, Manson SM: The place of culture in DSM-IV. J Nerv Ment Dis 1999, I 87(8):457-464.

10. SPINOCEREBELLAR ATAXIA 2; SCA2. Online Mendelian Inheritance in Man.

I I. MACHADO-JOSEPH DISEASE; MJD. Online Mendelin Inheritance in Man.

12. Gwinn-Hardy K, Chen JY, Liu HC, Liu TY, Boss M, Seltzer W, Adam A, Singleton A, Koroshetz W, Waters C, Hardy J, Farrer M: Spinocerebellar ataxia type 2 with parkinsonism in ethnic Chinese. Neurology 2000, 55(6):800-805

13. Subramony SH, Hernandez D, Adam A, Smith-Jefferson S, Hussey J, Gwinn-Hardy K, Lynch T, McDaniel O, Hardy J, Farrer M, Singleton $A$ : Ethnic differences in the expression of neurodegenerative 
disease: Machado-Joseph disease in Africans and Caucasians. Mov Disord 2002, 17(5): 1068-107I.

14. DENTATORUBRAL-PALLIDOLUYSIAN

DRPLA. Online Mendelian Inheritance in Man.

ATROPHY;

15. Burke JR, Wingfield MS, Lewis KE, Roses AD, Lee JE, Hulette C, Pericak-Vance MA, Vance JM: The Haw River syndrome: dentatorubropallidoluysian atrophy (DRPLA) in an African-American family. Nat Genet 1994, 7(4):521-524.

16. Rippon GA, Crook R, Baker M, Halvorsen E, Chin S, Hutton M, Houlden $\mathrm{H}$, Hardy J, Lynch T: Presenilin I mutation in an african american family presenting with atypical Alzheimer dementia. Arch Neurol 2003, 60(6):884-888.

17. Yoshiki A, Moriwaki K: Mouse phenome research: implications of genetic background. ILAR J 2006, 47(294-I02 [http:// dels.nas.edu/ilar n/ilarjournal/47 2/html/4702Yoshiki.shtml].

18. Hardy J, Singleton A, Gwinn-Hardy K: Ethnic differences and disease phenotypes. Science 2003, 300(5620):739-740.

19. Risch N: Dissecting racial and ethnic differences. N Engl J Med 2006, 354(4):408-4II.

\section{Pre-publication history}

The pre-publication history for this paper can be accessed here:

http://www.biomedcentral.com/1471-244X/7/1/prepub

Publish with Bio Med Central and every scientist can read your work free of charge

"BioMed Central will be the most significant development for disseminating the results of biomedical research in our lifetime. "

Sir Paul Nurse, Cancer Research UK

Your research papers will be:

- available free of charge to the entire biomedical community

- peer reviewed and published immediately upon acceptance

- cited in PubMed and archived on PubMed Central

- yours - you keep the copyright

Submit your manuscript here:

http://www.biomedcentral.com/info/publishing_adv.asp 